\title{
A CROSS-CURRICULAR APPROACH TO SPORT AND MATHEMATICS BY MEANS OF ICT
}

\author{
Marko Sonjak \\ Črna na Koroškem Primary school, Slovenia
}

\begin{abstract}
Students are usually more motivated to work in a sport class than in a math class. This research combined both subjects into one class. A combined class with a cross-curricular approach was introduced in the 6th year of primary school. Three teachers, who teach sport and math in the bth grade, jointly planned a lesson for refreshing the students' knowledge of basic geometrical concepts. To raise students' motivation for work, tablet computers were used in the class, and the Geogebra, Actionbound and Socrative applications. In the combined class, students had to use their bodies to illustrate different geometric notions. A symbol was chosen, and the students had to use sporting equipment to, by means of a relay, act out this symbol using their interrelationships. They had to pay attention to all the little details which are also important when drawing in a notebook. It was anticipated that recognizing geometric notions after that lesson would be at a higher level than before. The Socrative application was used at the end of the lesson to get a feedback on better understanding of the subject and to identify the positive effects of the cross-curricular approach.
\end{abstract}

Keywords: cross-curricular approach, ICT, primary school, useful knowledge

\section{Introduction}

An organized school system has been in place since the time of Maria Theresa, and it has since become one of the foundations of human society. On the verge of the new millennium, education systems across Europe were experiencing radical changes (Aberšek $\&$ Bregant, 2012). It tries to ensure the systematic acquisition of knowledge and offer equal opportunities for all members of society. The school is an integral part of our daily lives since the 18 th century and its guidelines have not changed much since then. On the other hand, civilization has experienced quite a bit of radical change since then. The industrial revolution, automation, and the introduction of robots in the workplace and, last but not least, computers and their impact on our daily lives. Especially with respect to the latter, there has been an exponential growth in their impact on our lives over the last two decades. All of this has of course also affected civilization, personal development, and the expectations of both the individual and society.

Never before has saying something about how "we were so different, as children, from the children of today" been more true, than in the 21 st century. Nowadays, people in their twenties can already see that the differences between their childhood and the children attending primary school today are more than obvious. It is precisely because of all the aforementioned influences that fundamental changes are necessary in society and also in the field of education. The times when students would sit quietly and listen to the teacher are gone. The amount of information we have access to today is simply incredible, and the proper selection of actual information presents a far bigger challenge than accessing it.

Maintaining motivation to work in the classroom is an increasing challenge. Among other things, students' interests are often stimulated by using ICT devices. This method has proven to be very effective but requires a considerable amount of knowledge and ingenuity. What is meant by ICT? ICT is a joint term for a wide variety of computer, information 
and communication devices (hardware), applications (software), networks (internet) and services (Institute of Informatics, 2017). Tišler (2006) said that we are recently witnessing a rapid development of ICT. People live in a time when social, economic and educational needs require the presence of technology. Today, computers and other information technology are used in all work environments and in all areas. That is why it is important to include ICT in the field of education as well.

\section{Connecting Mathematics and Sports}

As already mentioned in the summary, students are much more motivated to work in a sports class than in a math class, percentage-wise. The situation at the school, from which the sample for this research was taken, is similar. For this reason, the two subjects were combined into a single lesson, as part of this research.

Štemberger (2008) listed cross-curricular integration as one of the important didactic approaches that contributes to long-lasting and useful knowledge. Cross-curricular integration is presented by the author as a horizontal interconnection of the contents of various school subjects. If cross-curricular integration is to be effective, the objectives of individual areas must be clearly set out.

Because experiential learning is more effective and it has been scientifically proven that the human brain is much more active during movement than when sitting down and the same can be applied to memory, this study transferred mathematical subject matter into movement. Tablets were very helpful; working with them raised the level of motivation for learning in students. Tablets are generally very useful for performing tasks and making evaluation at the end of the class more interesting. This research was concerned with incorporating experiential learning into the classroom. Students illustrated their solutions either with their bodies or in some activities with props.

The motivational component of interdisciplinary integration should not be neglected, as motivation is the main factor that influences the active participation of students in lessons and learning (Videmšek et al., 2003).

Today, motivation is treated as an indirect variable of learning performance, which is directly proportional to the grades to some extent. Motivation amounts to approximately 10 percent of the grade, while we use individual's intellectual abilities to explain between 50 and 60 percent of learning achievement. Motivation is crucial, however, because without it, learning cannot happen at all (Juriševič, 2006).

The lessons were conducted in the 6th year, where basic geometric concepts had already been discussed. This material was then brushed up on during an interdisciplinary integration lesson. The evaluation was based on their self-evaluation and comparison of their own understanding of the subject matter before and after the lesson.

All tasks and activities were performed in the school gym. The students had to focus on the correct solution, which means that the result had to be displayed in the same way as if it were written in a notebook. In mathematics, it is very important that the drawn line is straight, that both ends of the line segment meet the drawn line, etc. The focus at the gym, to which the students' attention was especially drawn, was at the same level of detail. Before the start of the lesson, students and teachers discussed over what to pay attention to when solving the tasks. 


\section{Course of the Lesson}

Table 1

Layout and Content of the Lesson

\begin{tabular}{cccc}
\hline & Warm-Up & Main Part & Conclusion \\
\hline \multirow{3}{*}{ Content } & Playing as atoms & Relay - Geogebra & \\
& Playing true or false & Socrative quiz & Mentimeter \\
& Gymnastic exercises & Actionbound & \\
\hline
\end{tabular}

The lesson in the PE class started with a warm-up, which was made up of two games and gymnastic exercises. The first game involved running, as the students were moving around the room in a predetermined direction. The teacher announced a geometry concept aloud and the students illustrated it with their bodies. In this part, creativity was encouraged, so there is no specific way of showing the solution. The second game was true or false. The students listened to different statements by the teacher and kept their eyes closed, and if they agreed with the statement, they would keep standing, otherwise they would crouch down. Whoever misjudged a statement would have to perform a task (e.g., 5 squats) and then continue to take part in the game.

Gymnastic exercises were carried out in a standard form. During the exercises, especially in the first game, there was a discussion on the findings. Students reported about paying attention when drawing in their notebooks and discussed whether they adhered to these principles even when illustrating solutions with their bodies. Through the conversation, the students themselves came up with the basic rules in illustrating the solution of the task, which then had to be followed in the continuation of the lesson.

To perform the main part of the lesson, tablets with pre-installed applications were used. The first task in this part of the lesson was the relay. The students were divided into groups. Each group received a tablet computer. The group was stationed on one side of the gym and sports equipment was placed on the opposite side. Behind the group, sheets of paper with symbolic denotations of interconnected geometric concepts in three different difficulties were placed next to the wall. The sheets were turned around so that the students had to choose blindly, they only knew about the difficulty of the task. One of the students in the group selected a sheet and then each student made a drawing of the sketch of the solution in the Geogebra app on their tablet. The group chose the best or most correct sketch and, following its example, displayed the solution with the help of props. Only one student could go for the prop at a time and was allowed to take only one prop with him. The next student was able to go for the prop only when the first one had placed its prop in a suitable location according to the plan. In the end, the students photographed their solution, which was then evaluated in terms of difficulty and correctness. The props were put away and a new sheet of paper was selected. The execution of the task was limited in time in advance, the goal was to correctly display as many sheets as possible. 


\section{Figure 1}

Creating a Sketch in the Geogebra Application

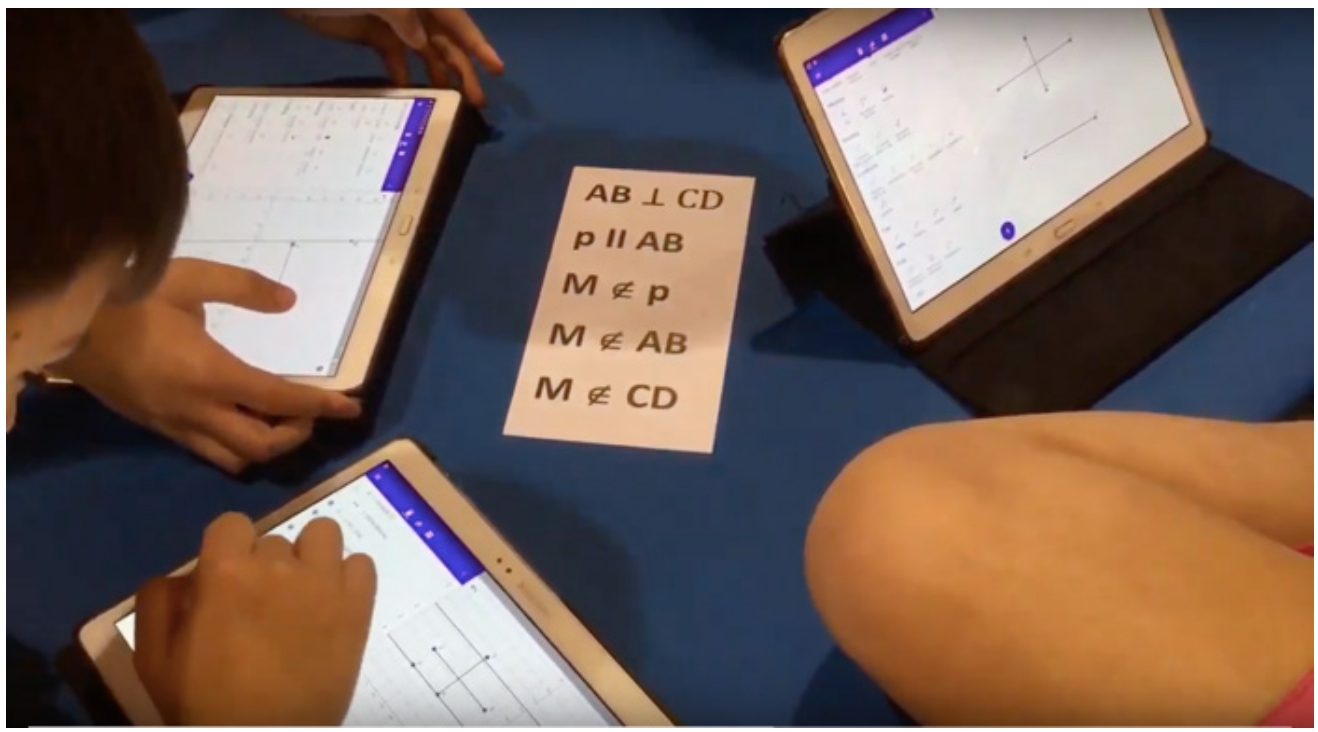

\section{Figure 2}

Performing a Task Using the Actionboud Application

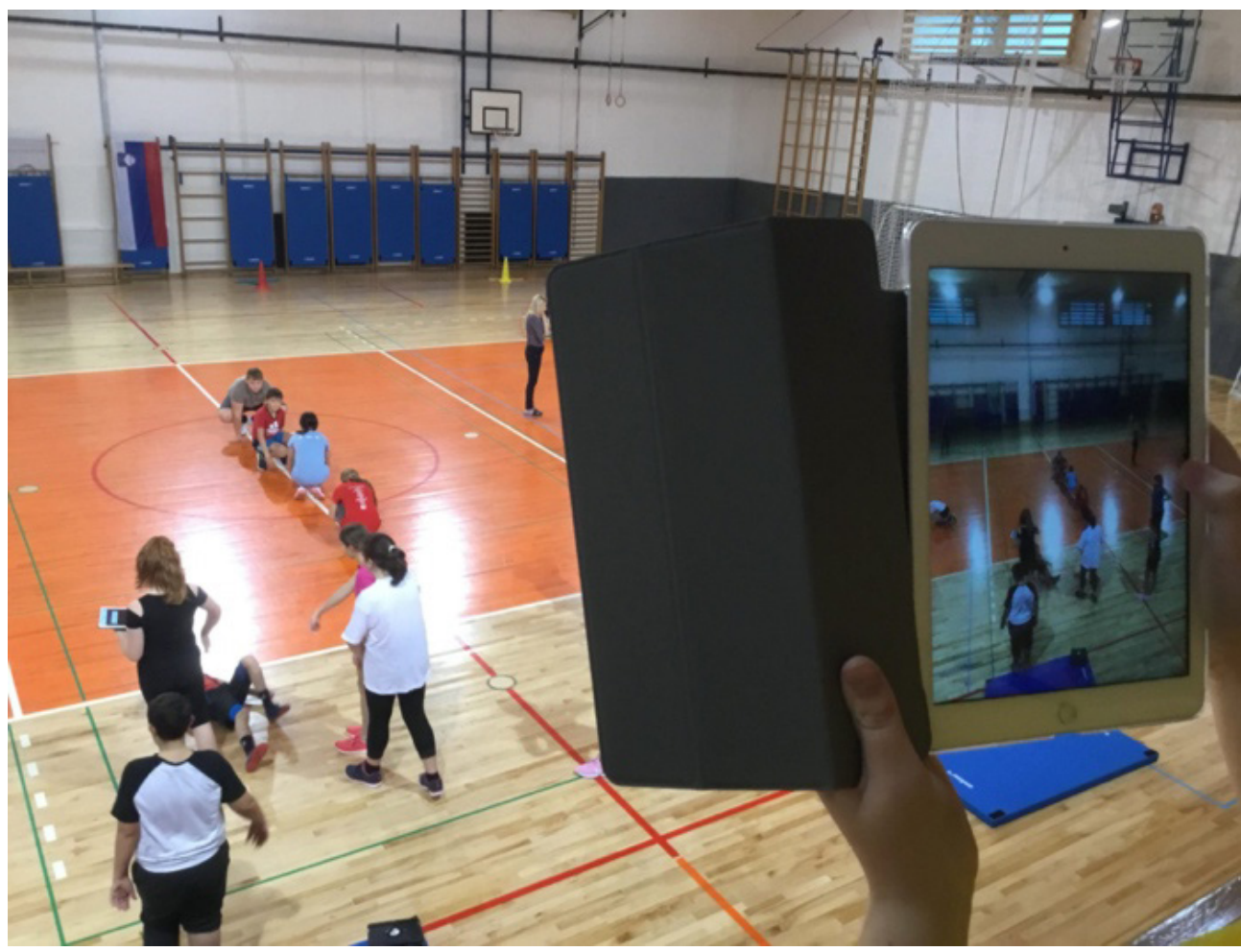




\section{Figure 3}

End-of-class Evaluation with the Mentimeter Application

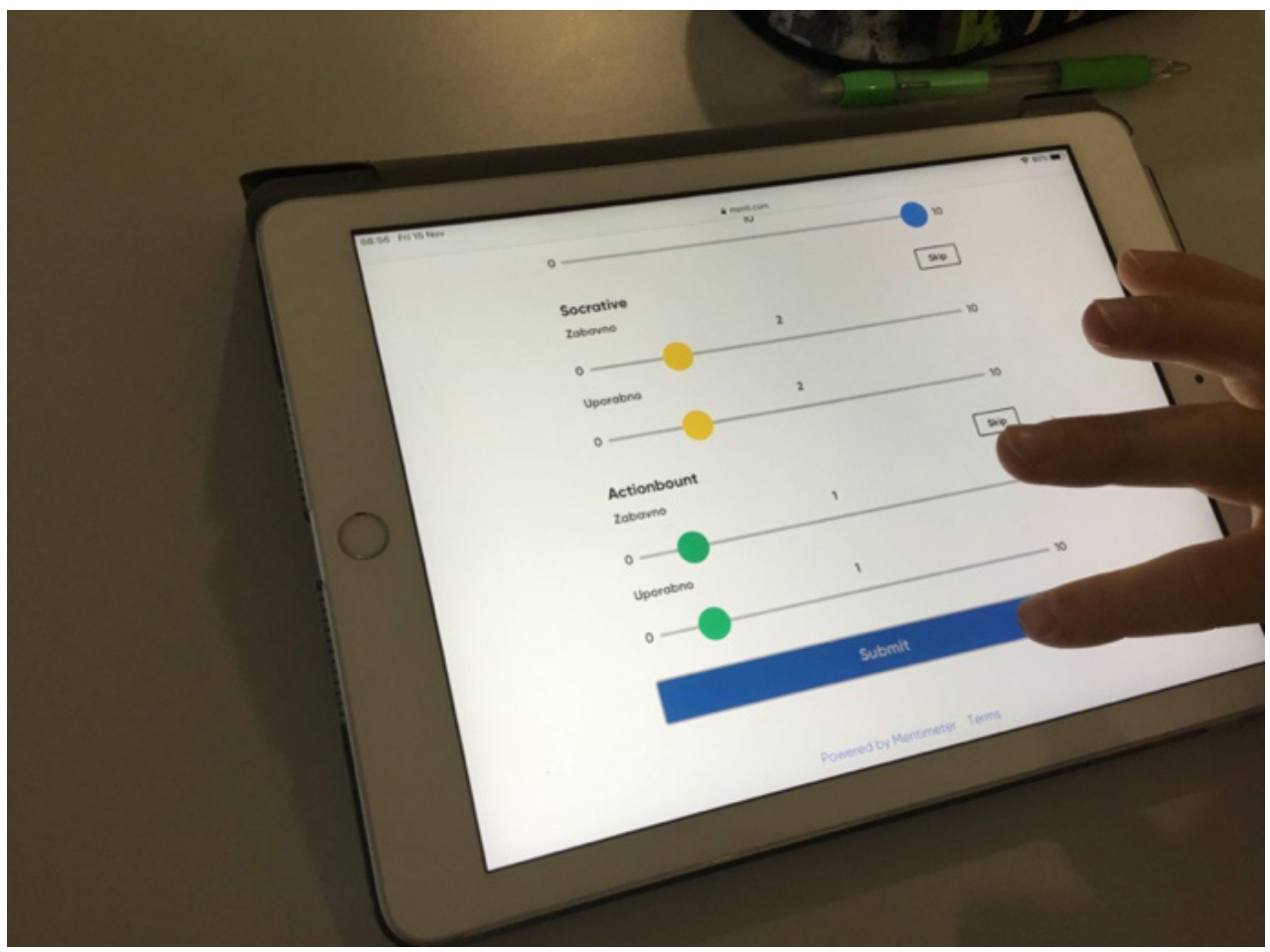

Another activity was solving a quiz in the Socrative app. Each student was solving a quiz on their tablet and for question they answered, they ran one lap around the cone. If the answer was wrong, they had to run two laps. For the last task, the Actionbound application was used. The students were, again, divided into groups. Tasks included illustrating symbols with their bodies, recording their solution, recording their explanation, and so on. In the end, they uploaded their solutions to an app where they were reviewed by the teachers. The end of the lesson was dedicated to the evaluation, which was performed using the Mentimeter application. The focus of this research was mainly on their understanding and their opinion about the lesson. This research was concerned with whether the students' understanding of the learning material was at a higher level after one lesson of interdisciplinary integration than before and whether this was influenced by the method of presenting the content or repetition. 


\section{Figure 4}

One of the Evaluation Results in the Mentimeter Application

\section{Oceni posamezno aplikacijo.}
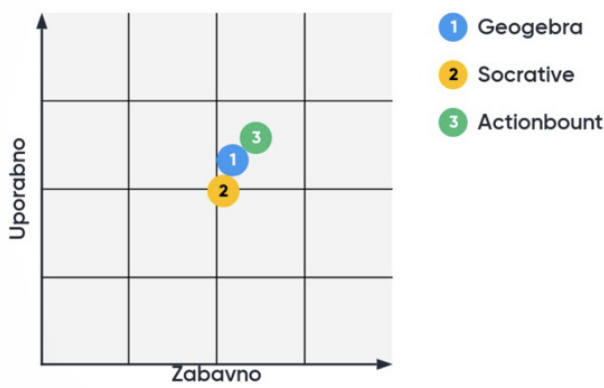

According to Romrell et al., (2014), teachers spend too much time trying to figure out what type of device they should use in class and how to get a sufficient number of devices. The more important question which deserves attention is how to use these devices to improve learning. According to the SAMR model, replacement and enrichment play a key role in improving teaching and learning (Jude et al., 2014). The use of technology in this research, according to the SAMR model, enriched the lessons, as the delivery of the content and the repetition of the already explained content was more efficient than it would be without it.

\section{Conclusions}

The implementation of the lesson required quite a bit of planning and coordination. The most time-consuming activity was probably downloading the software, providing the internet connection, and checking the performance of tablets computers for each student. Although the time schedule was thoroughly planned and the available time for the performance of each task was reduced in advance on multiple occasions, there was still a slight delay during the lesson and consequently a lack of time at the end of the lesson. The aim of this research was to incorporate a large number of ideas and prepare a very varied and interesting lesson for students. The activities were purposefully linked, although it would be also possible to skip some of them, thus spending more time performing the evaluation at the end of the class.

All teachers expected that the understanding of the content would be much better due to the practicality of the tasks and the intensive cooperation after the lesson. According to the results of the quiz and evaluation, this was unfortunately not the case. One of the reasons for that could be the fact that students who are slightly less well-versed in this knowledge were able to "hide" behind those who already understood the learning material during group activities. At the end-of-class evaluation, students pointed out that some students were in too much of a hurry and were more focused on running than on the questions. It was more important to them to be faster than others than to answer questions correctly. As a result, they were complacent and did not read the questions well. 
During the next math lesson, the teacher once again checked the understanding of basic geometric concepts and their symbolic denotations. She found that there was no progress in some children, but that there was a noticeable improvement in comprehension in some individuals as well as a clearly positive impact of the combined lesson of math and PE.

\section{References}

Aberšek, B., \& Bregant, J. (2012). The architecture of a school system according to the theory of dynamical systems. Problems of Education in the 21st Century, 46, 7-14. http://www. scientiasocialis.lt $/ \mathrm{pec} /$ node $/ 749$

Institute of Informatics. (2017). Osnovni pojmi IKT [Basic concepts of ICT]. FERI. https://ii.feri. um.si/sl/studij/osnovni-pojmi-itk/

Jude, T. L., Kajura, A. P. M., \& Birevu, M. (2014). Adoption of the SAMR model to assess ICT pedagogical adoption: A case of Makerere University. International Journal of e-Education, e-Business, e-Management and e-Learning, 4(2), $106-115$.

Juriševič, M. (2006). Učna motivacija in razlike med učenci [Learning motivation and differences between students]. University of Ljubljana, Faculty of Education.

Romrell, D., Kidder, L., \& Wood, E. (2014). The SAMR model as a framework for evaluating mLearning. Online Learning Journal, 18(2), 1-12. http://dx.doi.org/10.24059/olj.v18i2.435

Štemberger, V. (2008). Medpredmetno povezovanje in športna vzgoja [Cross-curricular integration and physical education]. Didakta, 18/19(12), 39-44.

Tišler, T. (2006). Spodbujanje uporabe informacijsko-komunikacijske tehnologije na osnovni šoli [Encouraging the use of information and communication technology in primary school]. In Tišler, T., Černilec, B., Vehovec, M., Korošec, D., Brezover, D., \& Pungartnik, S. (Ed.), Vodenje za spodbujanje informacijsko-komunikacijske tehnologije na šolah [Leadership to promote information and communication technology in schools] (pp. 11-23). Šola za ravnatelje.

Videmšek, M., Drašler, A., \& Pišot, R. (2003). Gibalna igra kot sredstvo za seznanjanje s tujim jezikom v zgodnjem otroškem obdobju [Movement play as a means of learning a foreign language in early childhood]. University of Ljubljana, Faculty of Sports, Institute of Sports.

Received 28 April 2021; Accepted 21 June 2021

Cite as: Sonjak, M. (2021). A cross-curricular approach to sport and mathematics by means of ICT. Gamtamokslinis ugdymas / Natural Science Education, 18(1), 29-35. https://doi.org/10.48127/gu-nse/21.18.29

\section{Marko Sonjak}

Teacher, Črna na Koroškem Primary school, Slovenia.

E-mail: marko.sonjak@os-crna.si

Website: http://www.os-crna.si/author/markosos-crna-si/ 